\title{
PENYULUHAN TENTANG PERAN KADER DALAM MENINGKATKAN KUALITAS PELAYANAN DI MASA PANDEMI
}

\author{
Sri Maria Puji Lestari ${ }^{* *}$, Ading Yogi Pratama², Zulfian ${ }^{3}$, Resti Arania ${ }^{4}$, Ni Putu \\ Sudiadnyan ${ }^{5}$, Ratna Purwaningrum ${ }^{6}$
}

Email Korespondensi: adingyogipratama354@gmail.com

\begin{abstract}
ABSTRAK
Berdasarkan keterangan, kecamatan Langkapura merupakan satu dari empat belas Kecamatan yang termasuk dalam kategori zona merah di Bandar Lampung. Pada 14 maret 2020, ditemukan pasien positif COVID-19 pertama di Lampung yaitu warga salah satu kelurahan di wilayah administratif Kecamatan Langkapura. Oleh karena itu peran kader sangat di perlukan dalam pelayanan. Salah satu upaya yang dapat dilakukan dengan memberikan pengetahuan. Tujuan dari kegiatan ini adalah untuk meniningkatkan pengetahuan mengenai covid. Pelaksanaan kegiatan dibantu oleh FK malahayati pada bulan Desember 2020. Hasil dari kegiatan ini adalah meningkatnya pengetahuan kader sehingga dapat disimpulkan bahwa penyuluhan pada kader sangat efektif.
\end{abstract}

Kata Kunci: Penyuluhan, kader, covid.

\begin{abstract}
Based on information, Langkapura sub-district is one of fourteen sub-districts included in the red zone category in Bandar Lampung. On March 14, 2020, the first positive COVID- 19 patient was found in Lampung, a resident of a sub-district in the administrative area of Langkapura District. Therefore, the role of cadres is needed in service. One of the efforts that can be done by providing knowledge. The purpose of this activity is to increase knowledge about Covid. The implementation of activities assisted by FK malahayati in December 2020. The result of this activity is the knowledge of cadres so it can be ignored that counseling to cadres is very effective.
\end{abstract}

Keywords: Counseling, cadres, covid 


\section{PENDAHULUAN}

COVID-19 (coronavirus disease 2019) adalah penyakit yang disebabkan oleh jenis coronavirus baru yaitu Sars-CoV-2, yang dilaporkan pertama kali di Wuhan Tiongkok pada tanggal 31 Desember 2019. (Kemenkes,2020). COVID-19 ini dapat menimbulkan gejala gangguan pernafasan akut seperti demam diatas $38^{\circ} \mathrm{C}$, batuk dan sesak nafas bagi manusia. Selain itu dapat disertai dengan lemas, nyeri otot, dan diare. Pada penderita COVID-19 yang berat, dapat menimbulkan pneumonia, sindromapernafasan akut, gagal ginjal bahkan sampai kematian. Kemenkes,2020). Virus ini dapat menimbulkan berbagai macam penyakit, diantaranya seperti flu hingga virus ini dapat menyebabkan penyakit yang lebih berat seperti Middle East Respiratory Syndrome (MERS-CoV) dan Severe Acute Respiratory Syndrome (SARS-CoV). (PDPI, 2020). Transmisi virus ini berlangsung sangat cepat dan mematikan dan menyebabkan banyak korban jiwa. Pada tanggal 11 Februari 2020, World Health Organization memberi nama virus baru tersebut dengan nama Severe acute respiratory syndrome coronavirus-2 (SARS-CoV-2) dan nama penyakitnya sebagai Coronavirus Disease 2019 (COVID-19). (PDPI, 2020).

Semakin hari banyak masyarakat yang telah menjadi korban akibat adanya virus ini. Organisasi Kesehatan Dunia (WHO) menetapkan secara resmi bahwa penyakit ini masuk ke dalam tahap "Darurat Kesehatan Global”. Di lansir dari data WHO sampai dengan tanggal 4 Desember 2020 telah dilaporkan sebanyak $64,603,428$ jiwa telah terkonfirmasi positif dan sebanyak 1,500,614 meninggal dunia. Saat ini lebih dari 100 Negara mengonfirmasi adanya virus tersebut. (WHO, 2020). Sementara di Indonesia menurut Kementrian kesehatan RI sampai tanggal 4 Desember 2020 terdata sebanyak 563.680 kasus terkonfirmasi positif dengan penambahan kasus per 4 Desember 2020 berjumlah 5.803 kasus terkonfirmasi positif, dan 17.479 kasus meninggal. Di Provinsi Lampung menurut data dari dinas kesehatan provinsi lampung sampai tanggal 21 Desember terdata sebanyak 5.479 terkonfirmasi Positif dengan jumlah kasus meninggal sebanyak 276 orang. Dengan jumlah pasien terkonfirmasi terbanyak di wilayah kot a Bandar Lampung dengan jumlah 2.449 orang.

Kader adalah seorang tenaga sukarela yang direkrut dari, oleh dan untuk masyarakat, yang bertugas membantu kelancaran pelayanan kesehatan. (Ismawati dkk, 2010). Tugas dari kader kesehatan masyarakat adalah sebagai pemberi informasi dan pelaku penyuluhan kepada masyarakat tentang informasi masalah kesehatan. Kader kesehatan harus mempunyai bekal pengetahuan dan ketrampilan untuk menyampaikan informasi dalam penyuluhan (Sulistyorini, 2010). Disisi lain, kader dituntun untuk dapat berperan aktif dalam memberikan pelayanan kesehatan kepada masyarakat. Dalam situasi pandemi COVID-19 kader diharapkan dapat memberikan edukasi dan pendidikan terhadap masyarakat dalam upaya pencegahan COVID-19. Menurut kepala dinas kesehatan kabupaten Cirebon Enny Suhaeni pada tanggal 9 Agustus 2020 mengumumkan ebanyak 5 kader terkonfirmasi Covid-19. Artinya Hal ini yang menjadikan kader menjadi kelompok yang sangat rentan dalam penularan COVID-19. (Kompas, 2020). Karena kader langsung bertemu masyarakat dalam melakukan pelayanan kesehatan. Maka dari itu kader dituntut untuk selalu waspada dalam melakukan setiap kegiatan pelayanan kesehatan. 
Kegiatan penyuluhan menjadi salah satu upaya untuk meningkatkan pengetahuan serta peran kader kesehatan mengenal pentingnya menjaga kesehatan dalam masa pandemi Covid-19. sebagai langkah awal untuk meningkatkan kesehatan. Pengetahuan yang baik akan berpengaruh terhadap perilaku kader dalam menjaga kesehatan dalam masa pandemi Covid-19. Tujuan dari penyuluhan ini adalah kader dapat memberikan pelayanan kesehatan yang baik kepada masyarakat sesuai protokol kesehatan dalam masa pandemi Covid19.

\section{MASALAH}

Berdasarkan keterangan, kecamatan Langkapura merupakan satu dari empat belas Kecamatan yang termasuk dalam kategori zona merah di Bandar Lampung. Pada 14 maret 2020, ditemukan pasien positif COVID-19 pertama di Lampung yaitu warga salah satu kelurahan di wilayah administratif Kecamatan Langkapura, daerah yang jadi salah satu radar kerja pelayanan kesehatan di Puskesmas Rawat jalan Segala Mider. Di Puskesmas tersebut belum pernah dilakukan penyuluhan khusus kepada para kader Kecamatan Langkapura mengenai teknis pelayanan yang perlu diperhatikan di saat era pandemi COVID19 ini. Sedangkan kader merupakan agen inti sebagai salah satu penunjang keberhasilan dalam pelaksanaan suatu kegiatan yang dilakukan oleh Puskesmas. Maka dari itu saya memilih sasaran para kader untuk memberikan sedikit kurangnya penyuluhan (edukasi) yang perlu diperhatikan di era pandemi COVID19 ini. Sehingga di harapkan setelah diberikan penyuluhan pada kegiatan ini, para kader mampu menjadi contoh kepada masyarakat dan bisa meningkatkan kualitas pelayanan terbaik untuk masyarakat setempat di era pandemi COVID-19 ini.

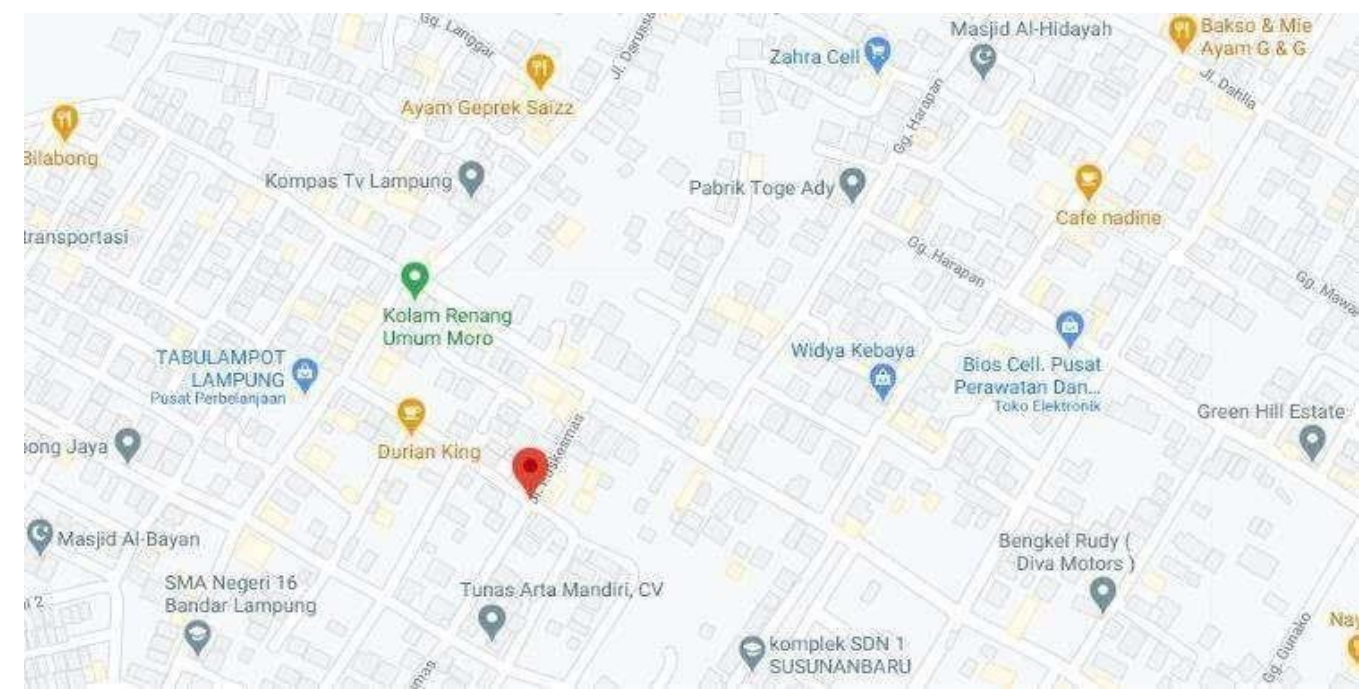

Gambar 2.1 puskesmas Segala Mider 


\section{METODE}

1. Tahap persiapan dari kegiatan adalah pembuatan pre-planning, mengajuakan izin dan persiapan tempat dan alat-alat lainnya disiapkan oleh pihak Kelompok 1 Fakultas Kedokteran Universitas Malahayati. Pembuatan power point dimulai 3 hari sebelum kegiatan penyuluhan dimulai.

2. Tahap pelaksanaan acara ini dimulai dengan mengadakan pre-test oleh Kelompok 1. Dilanjutkan dengan penyampaian materi kesehatan tentang Covid-19 oleh perwakilan Kelompok 1. Jika penyampaian materi telah selesai Kelompok 1 kembali mengadakan post-test.

3. Evaluasi

1. Struktur peserta hadir sebanyak 10 kader dari berbagai wilayah di sekitar Segala Mider. Setting tempat sudah sesuai dengan rencana yang dibuat dan perlengkapan yang dilakukan untuk penyuluhan sudah tersedia dan sudah digunakan sebagaimana mestinya. Penyampaian materi menggunakan bahasa yang mudah dimengerti oleh ibu kader. Dalam penyampaiannya, ibu kader dapat memahami materi yang sudah disampaikan dan selama berjalannya penyuluhan dilakukan diskusi serta tanya jawab untuk menarik minat ibu kader.

2. Proses pelaksanaan kegiatan dimulai pada pukul 09:00 s/d selesai WIB.

3. Hasil

1. Peserta dapat memahami dan mengerti tentang pengertian covid

2. Peserta dapat memahami dan mengerti tentang cara penularan covid

3. Peserta dapat memahami dan mengerti tentang gejala covid

4. Peserta dapat memahami dan mengerti tentang cara pencegahan covid

5. Peserta dapat memahami dan mengerti tentang peran kader dalam masa pandemi.

\section{HASIL DAN PEMBAHASAN}

Metode pelaksanaan kegiatan ini dilaksanakan pada tanggal 23 Desember 2020 di Aula Puskesmas Segala Mider. Sasaran kegiatan ini ditunjukan pada kader-kader. Alat-alat yang digunakan pada kegiatan ini adalah APD, masker, handscoon, sebagai contoh alat pelindung diri. Dan metode yang digunakan adalah ceramah dan Tanya jawab mengenai peran kader dalam meningkatkan kualitas pelayanan di masa pandemi. Selain itu metode lai yang digunakan adalah contoh memakai apd yang benar.

Evaluasi pelaksanaan penyuluhan dilakukan sebelum dan setelah intervensi menggunakan kuesioner pre test dan post test yang menunjukan terjadi peningkatan pengetahuan kader yaitu subjek dengan kategori baik yang sebelumnya $70 \%$ meningkat menjadi $80 \%$. Teknik penyuluhan ini dianggap baik untuk meningkatkan pengetahuan kader. 
Berikut gambar pelaksanaan penyuluhan:

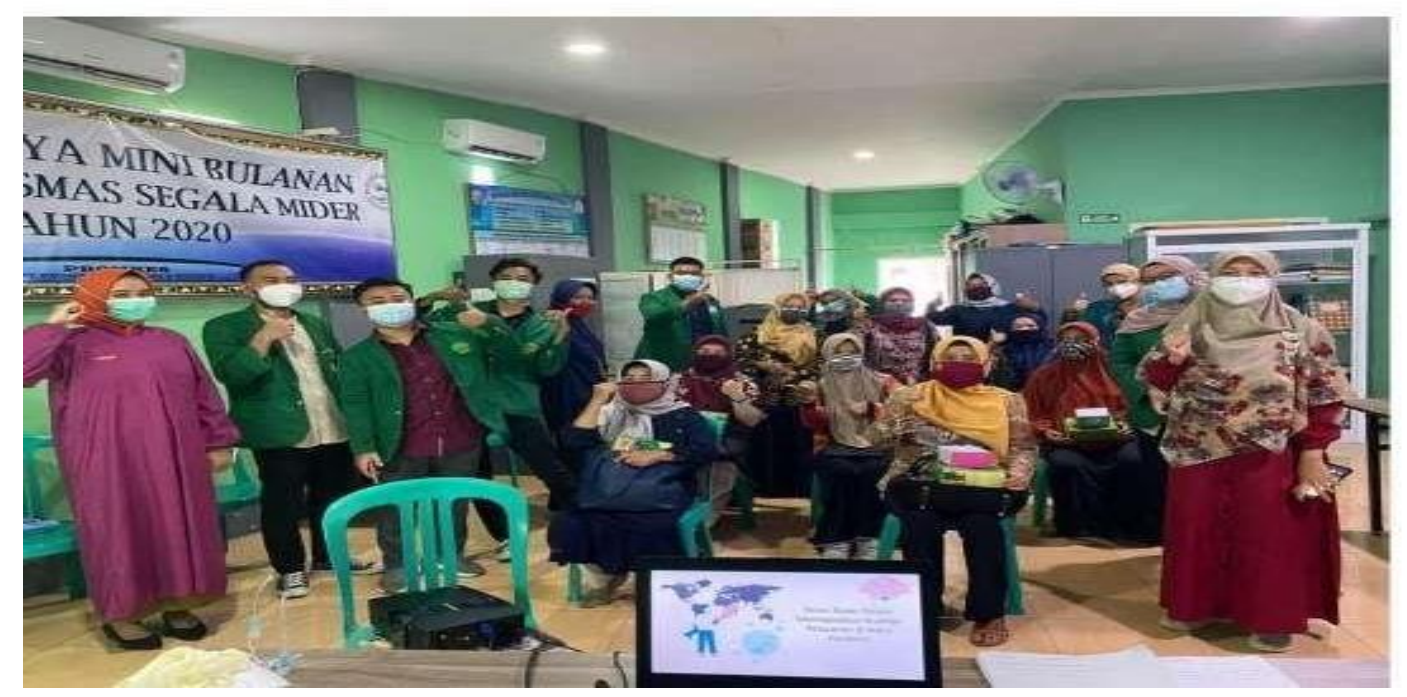

\section{KESIMPULAN}

Kegiatan pengabdian kepada masyarakat khususnya kepada kader-kader puskesmas dapat berjalan dengan baik dan benar. Peserta sangat aktif, antusias dan dapat bekerjasama dengan baik. Hasil dari kegiatan ini adalah meningkatnya pengetahuan kader tentang covid sebagai wujud meningkatkan pelayanan di masa pandemi.

\section{DAFTAR PUSTAKA}

Kemenkes RI. (2020). Hindari Lansia Dari Covid-19.http://padk.kemkes.go.id/. 21 Desember 2020. (00.36).

Perhimpunan Dokter Paru Indonesia (PDPI). (2020). Pneumonia Covid-19 Diagnosis \& Penatalaksanaan Di Indonesia. Perhimpunan Dokter Paru Indonesia. Jakarta.

PHEOC Kemkes RI. (2020). Coronavirus Disease 2019. https: //covid19.kemkes.go.id/. 4 Desember 2020. (14:21).

Pusdatin Bangda Provinsi Lampung. (2020). Dashbord Pemantauan COVID-19 Provinsi Lampung. https://www.covid19.lampungprov.go.id/. 21 Desember 2020 (00.05).

Romadhon. M. S. (2020). Tambah 19 pasien Positif Covid-19 di Cirebon https://amp.kompas.com/regional/read/2020/08/09/19251241/. Desember 2020.

Sari. I. R. (2018). Hubungan Pengetahuan Kader Tentang Tugas Dan Fungsi Posyandu Dengan Keaktifan Kader Di Wilayah Kerja Puskesmas Lombakasih Kabupaten Bombana Tahun 2018. Skripsi. Program Studi D-IV Kebidanan Politeknik Kesehatan Kendari.

WHO. (2020). Coronavirus Disease 2019. https://covid19.who.int/._4 Desember 2020. (14:15). 